\title{
FIXED CAPITAL INVESTMENT IN JANUARY-SEPTEMBER 2015
}

\author{
O.Izryadnova
}

In October 2015, fixed capital investment came to $94.8 \%$ and in JanuaryOctober-94.3\% against the same indicators last year. In October, the volume of construction constituted 92.1\%, commissioning of new living floor space$87.4 \%$ against indicators of October 2014. Prolonged contraction of construction volumes can result in collapse of business activity in construction and investment complex at the turn of 2016. The situation is getting worse due to high cost of credits and high inflation, which limit participation of private investors in the market.

Downward trend in fixed capital investment this year was rather foreseeable and was determined by contraction of fixed capital investment, which has been registered since Q2 2013. As of the period-end results for January-October 2015, fixed capital investment amounted to $94.3 \%$ and the volume of completed work in construction sector $-89.7 \%$ of indicators for the same period last year.

Dynamics of fixed capital investment is differentiated across small and large enterprises. In case of fixed capital investment reduction by $5.8 \%$ in the course of January-September

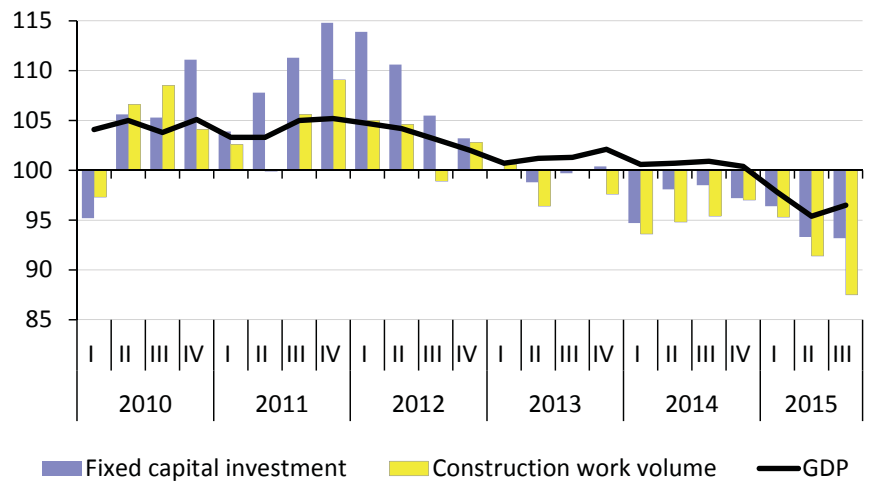

Source: Rosstat.

Fig. 1. Dynamics of fixed capital investment in 2010-2015, \% to corresponding quarter last year 2015 , its contraction in the segment of large and small enterprises came to $6.9 \%$. Such dynamics of the investment activity of large and medium enterprises has been observed in the intervening four quarters. Negative dynamics of fixed capital investment rate across complete set of sectors has been observed in the intervening eight quarters.

In January-September 2015, the structure of fixed capital investment saw a decrease in the volume and share of investment in construction of indus-

Table 1

\section{DYNAMICS OF PHYSICAL VOLUMES OF FIXED CAPITAL INVESTMENT IN JANUARY-SEPTEMBER 2009-2014, \% TO CORRESPONDING PERIOD OF PREVIOUS YEAR}

\begin{tabular}{|l|l|l|l|l|l|l|}
\hline $\begin{array}{l}\text { Fixed capital investment (basing on the full circle } \\
\text { of organizations including adjustment for investment } \\
\text { not observed by direct statistical methods) }\end{array}$ & 103.7 & 105.0 & 109.6 & 98.6 & 97.5 & 94.2 \\
\hline $\begin{array}{l}\text { Large and medium-sized organizations (fixed } \\
\text { capital investment not taking into account small } \\
\text { businesses and the volume of investments not } \\
\text { observed by direct statistical methods ) }\end{array}$ & 96.2 & 112.1 & 108.6 & 93.1 & 102.3 & 93.1 \\
\hline
\end{tabular}

Source: Federal State Statistics Service (Rosstat). 


\section{STRUCTURE OF FIXED CAPITAL INVESTMENT AS BROKEN BY TYPE OF FIXED ASSETS IN JANUARY-SEPTEMBER 2012-2015 \\ (LESS SMALL BUSINESS AND INFORMAL ACTIVITY PARAMETERS), \% TO TOTAL}

\begin{tabular}{|c|c|c|c|c|c|c|c|c|}
\hline & \multicolumn{4}{|c|}{$\mathrm{Rb} b n$} & \multicolumn{4}{|c|}{$\%$ to total } \\
\hline & 2012 & 2013 & 2014 & 2015 & 2012 & 2013 & 2014 & 2015 \\
\hline Fixed capital investment & 5461.4 & 5703.6 & 6070.1 & 6244.2 & 100 & 100 & 100 & 100 \\
\hline \multicolumn{9}{|l|}{ Of which: } \\
\hline Residential housing & 260.2 & 314.0 & 359.9 & 391.0 & 4.8 & 5.5 & 6.5 & 6.3 \\
\hline $\begin{array}{l}\text { Buildings (other than } \\
\text { residential buildings) } \\
\text { and facilities }\end{array}$ & 2847.1 & 2905.0 & 3011.2 & 3045.6 & 51.1 & 49.9 & 49.6 & 48.8 \\
\hline $\begin{array}{l}\text { Machines, equipment, } \\
\text { and means of transport }\end{array}$ & 1954.4 & 1992.6 & 2063.1 & 2063.4 & 36.6 & 37.0 & 34.0 & 33.0 \\
\hline Other & 399.7 & 492 & 599.9 & 744.2 & 8.0 & 9.0 & 11.9 & 11.9 \\
\hline
\end{tabular}

Source: Rosstat.

trial facilities and in machines and equipment. Redistribution of investment funds across types of fixed assets in the current year was unfolding under the impact of change in price structure on investment purpose products and services. With price growth at $8.4 \%$ on construction products leaving factory in September 2015 over December 2014, purchase price index for investment purpose machines and equipment went up by $13.0 \%$. Situation with ensuring commissioning of industrial facilities is aggravated by a simultaneous fall of domestic manufacture and import of investment purpose machines and equipment. Taking into account the difference in technological structure of fixed capital investment across industrial and non-production facilities, the most significant contraction of construction volumes happened in industry and agriculture.

In January-September 2015, real estate investment contracted by $8.5 \%$ in comparison with the same period last year. At the same time, in JanuarySeptember 2015, population's funds in co-funded construction down $\mathrm{Rb} 7.3 \mathrm{bn}$ against growth by $\mathrm{Rb} 53.3 \mathrm{bn}$ a year earlier. Amount of extended housing loans by the period-end for January-September 2015 constituted $\mathrm{Rb} 772.5 \mathrm{bn}$ or $61.6 \%$ of the last year's level. Last year undertakings determined positive dynamics in housing construction in Q1 2015. However, from the beginning of May 2015, dramatic slowdown was registered and in June-October, the fall of commissioned living floor space was observed. Positive dynamics of commissioned residential housing was observed since H1 2011 and was determined by somewhat improved situation with funding. However, considerable gap formed since late 2014 between rates of commissioning and building site work reflects a reduction of necessary undertakings' volumes, which with high probability, can lead to a deeper recession in the construction sector at the turn of 2016.

In 2015, fixed capital investment structure across types of economic activity has undergone some changes against last year. Contraction of investment into industry came to $2.1 \%$ in comparison with the corresponding period of the previous year. That said, increased growth of investment in extraction of natural resources by $13.2 \%$ in January-September 2015 over JanuarySeptember 2014 was followed by a reduction of fixed capital investment in manufacturing by $6.5 \%$ and in production and distribution of electricity, gas and water supply by $25.5 \%$. 
Structural shifts in manufacturing were determined by a fall of fixed capital investment in machine building complex by $5.1 \%$, in metallurgy - by $4.0 \%$, in production of coke and petroleum products - by $11.0 \%$ and in consumption complex - by $14.3 \%$ compared to $\mathrm{H} 1$ 2014. Features of capital investment changes in machine building complex in January-September 2015 was determined by investment growth in manufacture of electrical equipment, electronic and optical equipment by $29.6 \%$ and in manufacture

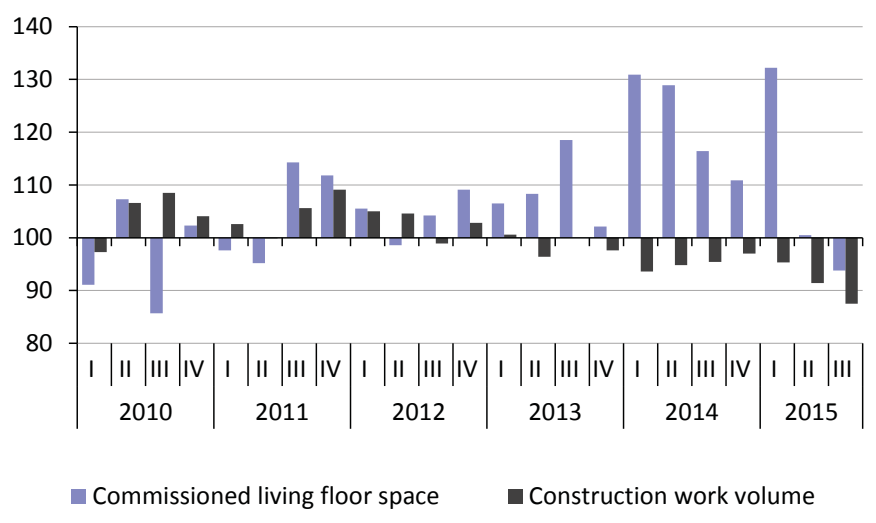

Source: Rosstat.

Fig. 2. Dynamics of commissioned new living floor space in 2010-2015, \% to corresponding period last year of machinery and equipment - by $15.0 \%$ with a reduction of fixed capital investment in manufacture of means of transport by $21.7 \%$ against January-September 2014.

In the wake of a reduction of capital investment volume, contraction of investment in the development of associated producing units in metallurgical and construction complexes and manufacture of structural materials was reported.

Another specific feature of January-September 2015 was accelerating fixed capital investment in chemical industry by twofold. This is linked both with increased export potential of this sector and with import substitution.

In short- and medium-term future, Industry Development Fund (IDF) can provide financial support to industrial enterprises in compliance with the Federal Law 'On Industrial Policy in the Russian Federation' (№ 488-FZ of 31.12.2014). In 2015, IDF approved loans to the tune of $\mathrm{Rb} 20 \mathrm{bn}$ aimed at the implementation of 59 import substitution projects totalling over Rb 162.3bn, of which private investments come to nearly Rb $142 \mathrm{bn}$. According to IDF data, nearly all Fund's assets were invested in machine building ( $R b$ 6.6bn) and pharmaceutical industry ( $\mathrm{Rb} 3.9 \mathrm{bn}$ ).

In the context of economic growth incentives, priority should be given to infrastructure development. However, investment contraction in transport and communications over January-September 2015 came to $10.7 \%$ compared to January-September 2014. Furthermore, investment in pipeline transport shrank by $14.6 \%$. Contraction of domestic demand predetermined investment reduction in the development of commerce, hotel and restaurant business.

Funding of investment was determined by stronger focus on the use of equity capital. In January-September 2015, the share of equity-capital investment amounted to $54.4 \%$ and by 4.2 p.p. exceeded 2014 index. In JanuarySeptember 2015, the cost effectiveness across the economy at large stood at $9.5 \%$, up 0.8 p.p. against the corresponding period last year, which resulted in increased investment financed by corporate profit. Borrowed assets for capital investment in January-September 2015 shrank by Rb 173.7bn compared to last year index.

The banking sector participation in funding investment has dropped noticeably. In January-September 2015, the share of bank loans in the structure of funding sources stood at $8.7 \%$ and was by 1.1 p.p. below the index of 
FIXED CAPITAL INVESTMENT (LESS SMALL BUSINESSES AND INVESTMENT WHICH CANNOT BE MEASURED BY DIRECT STATISTIC METHODS) IN JANUARY-SEPTEMBER 2012-2015

\begin{tabular}{|c|c|c|c|c|c|c|c|c|}
\hline & \multicolumn{4}{|c|}{$\begin{array}{l}\text { Growth rate, \% of correspond- } \\
\text { ing period of previous year }\end{array}$} & \multicolumn{4}{|c|}{ Structure, $\%$ to total } \\
\hline & 2012 & 2013 & 2014 & 2015 & 2012 & 2013 & 2014 & 2015 \\
\hline Total & 108.6 & 93.1 & 102.3 & 93.1 & 100 & 100 & 100 & 100 \\
\hline Agriculture & 97.1 & 103.5 & 110.6 & 96.5 & 3.2 & 3.4 & 3.3 & 3.5 \\
\hline fishing, fish farming & 174.7 & 93.8 & 56.2 & 70.9 & 0.1 & 0.1 & 0.1 & 0.1 \\
\hline industrial sector & 115.2 & 92.1 & 105.2 & 97.9 & 49.2 & 50.7 & 51.5 & 53.9 \\
\hline mineral extraction sector & 115.8 & 93.1 & 107.4 & 113.2 & 20.3 & 21.2 & 22.2 & 26.3 \\
\hline $\begin{array}{l}\text { Extraction of fuel and energy } \\
\text { natural resources }\end{array}$ & 115.6 & 90.8 & 109.7 & 113.0 & 18.4 & 19 & 20.2 & 24.0 \\
\hline manufacturing sector & 115.4 & 103.0 & 105.0 & 93.5 & 17.2 & 18.5 & 18.8 & 19.2 \\
\hline $\begin{array}{l}\text { Production and supply of } \\
\text { electricity, gas and water }\end{array}$ & 113.2 & 90.6 & 101.3 & 74.5 & 11.7 & 11 & 10.5 & 8.4 \\
\hline construction sector & 80.2 & 98 & 95.9 & 74.0 & 1.8 & 1.9 & 2.2 & 1.5 \\
\hline wholesale and retail commerce & 106.6 & 113.5 & 99.9 & 98.0 & 2.1 & 2.7 & 2.7 & 2.8 \\
\hline hotels and restaurants & 64.2 & 134.7 & 106.3 & 28.1 & 0.3 & 0.8 & 0.8 & 0.4 \\
\hline transports and communications & 102.4 & 81.5 & 100.6 & 89.3 & 26.2 & 21.5 & 20.5 & 19.8 \\
\hline railway transport & 99.7 & 84.1 & 78.1 & 86.7 & 4.6 & 3.8 & 3.1 & 3.2 \\
\hline pipeline transport & 96.3 & 66.6 & 117.2 & 85.4 & 9.8 & 6.5 & 7.1 & 6.4 \\
\hline communications & 105.2 & 84.2 & 117.0 & 86.4 & 3.3 & 2.8 & 3.2 & 3.1 \\
\hline financial business & 127 & 89.4 & 78.5 & 78.0 & 1.6 & 1.7 & 1.3 & 1.3 \\
\hline real estate operations & 113.1 & 100.3 & 116.0 & 91.5 & 7.8 & 9.1 & 10.8 & 10.8 \\
\hline public administration & 104.4 & 91.5 & 86.4 & 99.3 & 1.4 & 1.4 & 1.2 & 1.2 \\
\hline education & 96.2 & 99.9 & 112.2 & 99.5 & 1.6 & 1.6 & 1.7 & 1.8 \\
\hline $\begin{array}{l}\text { healthcare and provi- } \\
\text { sion of social services }\end{array}$ & 114.7 & 98.1 & 75.2 & 80.1 & 1.7 & 1.7 & 1.3 & 1.1 \\
\hline Provision of other services & 111.1 & 117.1 & 75.3 & 70.2 & 3.0 & 3.4 & 2.5 & 1.8 \\
\hline
\end{tabular}

Source: Rosstat.

the corresponding period last year. Changes in the structure of bank loans is marked by a falling amount and share of loans extended by Russian banks. In comparison with January-September 2014, Russian banks' loans dropped by $\mathrm{Rb} 122.9 \mathrm{bn}$. Increased volume and share of loans extended by foreign banks and foreign investment are explained by revaluation of foreign currency in roubles in current prices.

Capital flight exerted negative influence on the level of banks' participation in financing investment projects in January-September 2015. According to preliminary estimates of the Bank of Russia, net outflow of capital conducted by private sector constituted USD 45.0bn in January-September 2015 of which by the banking sector - USD 28.0bn.

The role of budget funds appeared to change in the structure of assets raised to finance fixed investment. In January-September 2015, Rb 871.8bn of fixed investment was financed by budget funds $(14.0 \%$ of total investment in economy).

To compare with January-September 2014, financing of investment with federal budget resources increased by $\mathrm{Rb} 70.8 \mathrm{bn}$ and offset reduction of expenditure of RF subjects and of local budgets allocated on investment.

In Russia, higher authorities' assets most often than not are represented by large holdings, joint stock companies and financial and industrial groups with state participation. Reduced activity of these investors in the course 
Table 4

DYNAMICS AND STRUCTURE OF FIXED CAPITAL INVESTMENT BY SOURCE OF FINANCING IN JANUARY-SEPTEMBER 2012-2015 (LESS SMALL BUSINESSES AND INVESTMENT VOLUME WHICH CANNOT BE MEASURED BY DIRECT STATISTIC METHODS), \% TO TOTAL

\begin{tabular}{|c|c|c|c|c|c|c|c|c|}
\hline & \multicolumn{4}{|c|}{$\mathrm{Rb}$ bn } & \multicolumn{4}{|c|}{$\%$ to total } \\
\hline & 2012 & 2013 & 2014 & 2015 & 2012 & 2013 & 2014 & 2015 \\
\hline Fixed capital investment & $5,461.4$ & $5,703.6$ & $6,070.1$ & $6,244.2$ & 100 & 100 & 100 & 100 \\
\hline Equity & $2,604.3$ & $2,797.1$ & $3,047.7$ & $3,395.5$ & 47.7 & 49 & 50.2 & 54.4 \\
\hline Borrowed funds & $2,857.1$ & $2,906.5$ & $3,022.4$ & $2,848.7$ & 52.3 & 51 & 48.8 & 45.6 \\
\hline Bank loans & 444.8 & 566.7 & 596.3 & 542.4 & 8.2 & 9.9 & 9.8 & 8.7 \\
\hline Including loans from foreign banks & 80.2 & 60.5 & 71.0 & 140.0 & 1.5 & 1.1 & 1.2 & 2.2 \\
\hline Borrowed from other organisations & 307.9 & 386.9 & 414.6 & 366.5 & 5.6 & 6.8 & 6.8 & 5.9 \\
\hline Foreign investments & 179.8 & 144.8 & 51.2 & 53.0 & 3.3 & 2.5 & 0.9 & 0.8 \\
\hline Budgetary funds & 777.6 & 877.6 & 845.9 & 871.8 & 14.2 & 15.4 & 13.9 & 14.0 \\
\hline Federal budget funds & 384.2 & 462.3 & 424.5 & 495.3 & 7 & 8.1 & 7.0 & 7.9 \\
\hline $\begin{array}{l}\text { Funds from budgets } \\
\text { of subjects of the Federation }\end{array}$ & 339.9 & 362 & 359.3 & 316.2 & 6.2 & 6.4 & 5.9 & 5.1 \\
\hline From local budgets & 53.5 & 53.3 & 62.1 & 60.3 & 1 & 0.9 & 1.0 & 1.0 \\
\hline Non-budgetary funds & 14.6 & 20.7 & 12.0 & 13.7 & 0.3 & 0.4 & 0.2 & 0.2 \\
\hline $\begin{array}{l}\text { Funds of organizations and } \\
\text { population borrowed for } \\
\text { shared-equity construction }\end{array}$ & 115.8 & 145.6 & 207.6 & 205.5 & 2.1 & 2.6 & 3.4 & 3.3 \\
\hline Including funds of population & 76 & 116.8 & 170.1 & 162.2 & 1.4 & 2 & 2.8 & 2.6 \\
\hline Other & $1,196.4$ & 909 & 894.8 & 795 & 21.9 & 15.9 & 15.9 & 12.7 \\
\hline Funds of parent organisations & $1,033.6$ & 685.6 & 743.7 & 597.7 & 18.9 & 12 & 12.3 & 9.6 \\
\hline $\begin{array}{l}\text { Funds from the issue of } \\
\text { corporate bonds }\end{array}$ & 0.05 & 5 & 5.3 & 94.6 & 0 & 0.1 & 0.1 & 1.5 \\
\hline Funds from the issue of shares & 62.8 & 50.6 & 53.6 & 30.7 & 1.1 & 0.9 & 0.9 & 0.5 \\
\hline
\end{tabular}

Source: Rosstat.

of 2013-2015 exceptionally negatively reflected on the general dynamics of capital investment. The share of fixed capital investment from higher authorities' resources in the structure of financing sources fell from $12.3 \%$ in January-September 2014 to $9.5 \%$ in January-September 2015. In absolute terms, this reduction comes to $\mathrm{Rb} 146 \mathrm{bn}$.

In January-September 2015, increase of issues of corporate securities by eighteen-fold had a positive effect on financing of investment against January-September 2014. This growth offset a sharp reduction of funds generated by shares issuance and became an additional source of investment.

Amid 2015 trends, we expect a reduction of capital investment by $10 \%$, which will determine start up conditions for construction and investment complex performance in 2016. 